\title{
Rehearsal for the (Robot) Revolution
}

\author{
Elizabeth Jochum
}

Aalborg University

Rendsburggade 14

9000 Aalborg, DK

jochumehum. aau.dk
Ken Goldberg

University of California Berkeley

425 Sutardja Dai Hall, Berkeley, CA

94720

goldberg@berkeley.edu

\begin{abstract}
.
This paper considers the use of tele-operated and autonomous robots in live performance. The word "robot" traces its lineage to theatre, and theatre has proved a conducive site for studying what makes robots compelling. Theatre is a narrowly defined domain in which robots can excel; however automated performances that merely substitute robotic actors for human ones are not always engaging. While some plays explore ambivalence to robots or "misbehaving machines" thematically (like R.U.R.), the exigencies of live theatre (unlike film) do not allow for editing or special effects. This means that robots must be highly calibrated and run the risk of appearing like over-rehearsed actors. How do artists create engaging performances while ensuring reliable and robust performances?

This paper considers design and approaches to staging robots in live theatre and interactive art. Citing examples of machinic performances absent of human actors (Le Cour de Miracles; Stifter's Dinge), interactive robotic art (Telegarden; Six Robots Named Paul), human-robot opera and musicals (Death and the Powers; King Kong), puppetry (Pygmalion Project; Savanna; How to Train Your Dragon), and traditional spoken-word plays (I, Worker; Sayonara; All in the Timing; Fremtiden), we demonstrate how creative approaches to robot dramaturgy and puppetry-inspired control techniques create compelling and interactive performances. Theatre performances function as authentic sites of human-robot interaction staged in fictional landscapes that both exaggerate and occlude the capabilities of robots.
\end{abstract}

Keywords. Art Robots Performance Uncanny 